\title{
Protection of stratigraphic sections in China - a suggested model for important global reference outcrop sections
}

\author{
${ }^{1}$ China National Commission on Stratigraphy, 26 Baiwanzhuang Road, Beijing 100037, China \\ ${ }^{2}$ Department of Geological Environment, Ministry of Land and Resources of China, Xisi, Beijing 100034, China \\ ${ }^{3}$ School of Earth Sciences and Resources, China University of Geosciences, Xueyuan Road, Beijing 100083, China \\ ${ }^{4}$ Department of Earth, Atmospheric and Planetary Sciences, Purdue University, 550 Stadium Mall Drive, West Lafayette, IN 47907-2051, \\ USA; State Key Laboratory of Biogeology and Environmental Geology, School of Earth Sciences, China University of Geosciences, Wuhan, \\ Hubei 430074, China \\ ${ }^{5}$ Institute of Geology, Chinese Academy of Geological Sciences, 26 Baiwanzhuang Road, Beijing 100037, China; *Corresponding author, \\ E-mail:hou_hongfei@126.com
}

(Received: March 6, 2017; Revised accepted: August 14, 2017)

http://dx.doi.org/10.18814/epiiugs/2018/v41i1/018001

The protection of classical or significant reference stratigraphic sections of the nation's valuable geoheritage has become a priority by the Chinese government and national stratigraphic commission. The process for the protection and documentation of stratigraphic sections includes: (1) marked tablets showing the standardized bed, member and formation divisions and, where applicable, standardized meter intervals for future investigations; (2) a monument or other on-site interpretive information; and (3) field guides for different audiences summarizing its importance with maps and detailed descriptions. In particular, the ten Global Stratotype Sections and Points (GSSPs) established in southern China are well preserved and managed; and some are now within tourist-friendly educational national geoparks. We suggest that other national stratigraphic commissions might incorporate some of the experiences from China's current efforts to preserve and standardize important reference sections for Earth history research.

\section{Importance of Preserving and Documenting Major Reference Sections of Earth's History}

Our understanding of Earth's fascinating history has been partially established from the study of well-preserved continuous stratigraphic sections. In each region, there are important reference sections that either are the standard definitions for regional stratigraphic divisions and/or provide a detailed record of major environmental and climate trends, biologic evolution or migration episodes, geochemical excursions, sea-level fluctuations, magnetic reversal patterns of regional to global significance. A few of these major reference sections throughout the globe have also been selected as the Global Stratotype Sections and Points (GSSPs) for defining the international geologic time scale. In order to apply new techniques or to achieve enhanced inte- grated correlations, research teams constantly revisit many of these reference sections. Future research with these reference sections, especially the GSSPs, requires being able to precisely locate new sampling with respect to past publications. However, especially for longer sections with numerous similar-looking bedding, it can be difficult to accurately obtain a consistent "meters from a marker bed" or to confidently identify "Bed xx" that was used in historically important studies.

Borehole cores, especially those from the ocean drilling programs (DSDP, ODP, IODP) and curated cores in geologic survey or corporate storage archives, have standardized meter scales for future sampling. However, natural outcrops or abandoned quarry excavations often present a challenge for comparing investigations because different groups employ non-uniform bed nomenclature and meter measurements.

Geoscientists publish their exciting discoveries from such reference sections in scientific journals, but often there is no "on-site" outreach to inform the general public about the importance of these outcrops or the compilation and updating of easily-accessible guides for future educational field trips. It would greatly enhance the visibility and appeal of geoscience detective work if all people were empowered to learn about Earth's history when looking at the actual rocks.

Many nations have made extensive efforts to celebrate their GSSPs by monuments (Czech Republic, Spain, etc.) and to promote their unique or relevant regional Earth history with geo-heritage sites and Global Geoparks. China has made a concerted effort since the 1990s to compile a priority list of major reference sections for onsite documentation and to protect and promote its geoheritage with the construction of geoparks. In May 1995, the Ministry of Geology and Mineral Resources of China (http://www.mir.gov.cn) issued "Regulations on Geoheritage Protection, in which "typical stratotype sections (including parastratotype sections) and biostratigraphic sections which are of significant scientific research value to learn geological history" stipulated that these sections are one type of geoheritage under protection. The Regulations also clarified the responsibilities and authorities of land and resources departments under local governments at various levels to 
carry out geoheritage protection. In 2013, the China National Commission on Stratigraphy set up a special organization for section protection and formulated detailed rules for implementing section documentation and protection. This stratigraphic section protection program has had an orderly and sustained development.

In this paper, we present some aspects and methods being employed in China for stratigraphic section protection, with the dual goals of enabling future research and of increasing science knowledge of the public.

\section{Characteristics of the Identified Special Stratigraphic Sections}

A few special stratigraphic sections have become regarded as "the main pages in Earth's history book" for research on paleoenvironment, paleogeography, paleoclimate, paleobiology, paleomagnetism and biological evolution. For example, the Web of Science (Feb, 2017) lists over 200 publications that refer to the Permian-Triassic boundary section near Meishan (Fig. 1). Others serve as standards to define chronostratigraphic units. Such stratigraphic sections are the nation's nonrenewable wealth.

Thanks to the complex and favorable geological and geographic conditions in the Chinese territory, a large number of stratigraphic sections record significant geological events from Precambrian through Holocene. According to the preliminary survey by the National Commission on Stratigraphy, the typical province in China has about 50 stratigraphic sections worthy of special protection. Even though the ca. 500 sections throughout entire China sounds daunting for documentation and preservation, it is a manageable number.

The process for identifying and allocating funding begins with setting priorities for sections by working groups of the National Commission, then a dual procedure of explaining the situation to local authorities and adjacent inhabitants and assigning development funds from the Ministry of Land and Resource Management to those local offices. For sections on land being used by farmers or industries (e.g.,

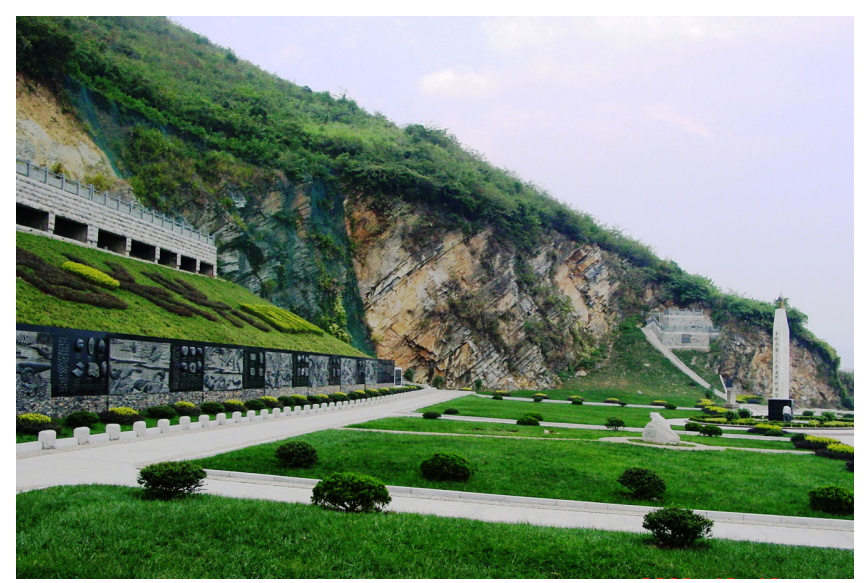

Figure 1. Changxing Geopark at Meishan, Zhejiang province, established to host the international Global Boundary Stratotype Sections and Points (GSSPS) for both the base of the Changhsingian Stage (uppermost Permian; right side of photo) and the base of the Induan Stage (Permian-Triassic boundary; left side of photo). Photograph courtesy of $S$. Peng. quarries), then an appropriate compensation and oversight of the appropriate location is arranged.

The identified priority key stratigraphic section resources in China have the following characteristics:

\section{Special Global or Regional Standards}

The China National Commission on Stratigraphy classifies these stratigraphic sections into three levels for protection and documentation:

(1) International GSSPs, of which there are currently ten in South China (Gradstein et al., 2012; Peng et al., 2016; https://engineering. purdue.edu/Stratigraphy/gssp/). These GSSPs defining international geologic stages are the foundation of the global geologic time scale (International Chronostratigraphic Chart of the International Commission on Stratigraphy; http://www.ics.org), and were chosen after extensive multi-disciplinary study to document their value for global correlation. The International Commission on Stratigraphy has discussed recommending to UNESCO that GSSPs be recognized as geoheritage site to elevate the importance of their preservation and scientific usage.

(2) National standards for regional chronostratigraphic divisions. With the implementation of the Stratigraphical Research Project on Stage Construction in China, in-depth research has been conducted on 59 out of the 102 stages defined in the China Regional Chronostratigraphical Scale (Zhang et al., 2015); and the associated standard documentation and protection of these principle reference sections is underway.

(3) Regional geological mapping standards (formation to group level).

\section{Significance for Global Correlation}

In addition to the chronostratigraphic and geologic mapping standards, the Regulations on Geoheritage Protection promulgated by the former Ministry of Geology and Mineral Resources of China, designate the following:

(1) Stratigraphic sections containing rare or characteristic fossils, or biostratigraphical units with global correlation significance.

(2) Stratigraphic sections with the potential to carry out regional to global correlation.

(3) Stratigraphic sections with important geological characteristics, for instance, records of tectonic and sedimentation events.

\section{Scientific Value}

China is endowed with geological conditions and different paleobiogeographic regions that have preserved unique global records. For example, the North China block contains one of the world's best thick successions of unmetamorphosed early Mesoproterozoic and early Neoproterozoic strata (1800-780 Ma) with rich fossils (e.g., Chen et al., 1980), and Mesozoic strata with feathered dinosaur and primitive bird fossils (e.g., Chang, 2004). The Three Gorges region has continuous late Neoproterozoic sections documenting glacial episodes (e.g., Lee, 1936; Zheng et al., 2007; Zhang et al., 2008) and the evolution of microfossils through small shelly fossils. South China block hosts 
complete marine strata from Paleozoic to Triassic, forming continuous stratigraphic sequence and containing rich paleontological records. The Quaternary loess blanketing much of central eastern China record the Cenozoic history of Asian glaciations (e.g., An et al., 1990; Ding et al., 2002). All these stratigraphic sections are of typical and special geological value.

\section{Geoscience Popular and Aesthetic Value}

The first National Geological Nature Reserve established (1985) in China was "the Middle-Upper Proterozoic Stratigraphic Section" (Jixian, Tianjin) for a Precambrian stratigraphic section spanning a thickness over 2 kilometers. The Changxing National "Golden Nail" Geopark at Meishan in Zhejiang province hosts both the Permian-Triassic (Paleozoic-Mesozoic) boundary and the Wuchiapingian-Changhsingian stage boundary (upper Permian) GSSPs (Fig. 1) next to a multimedia museum on Earth history. This Meishan Geopark received about 100,000 visitors during 2016 and has 32 employees. Longmenshan National Geopark in Jiangyou, Sichuan province, is characterized by its Devonian section. Dozens of other national geoparks have been established for popularization of geoscience and Earth history; and the development of geo-tourism has greatly boosted the economic development of the local communities. When the local residents and government understand the educational and scientific value of their geologic treasures, then they take pride in maintaining and promoting these important sites.

\section{Sampling Protection}

Permission and access for sampling of international-reference sections (e.g., GSSPs) are arranged through the relevant regional authorities, usually the Province-level Bureau of Land and Resource Management, and should involve a person from a national university or other institution for logistical guidance and responsibility for overseeing appropriate sampling. National reference sections do not require permission for sampling. Besides protection of the stratigraphic section in the field, related research results (intellectual property rights or IPR) and specimen preservation should also be protected, but this process is not yet established. In the future, researchers could submit related research results to gain IPR protection, and the National Commission would help to set up a stratigraphic database associated with each reference section. Orderly storage of specimens shall also be realized.

\section{Standardization of Stratigraphic Section Protection}

Most GSSPs in China are classified as national geoparks in which strict documentation and protection measures include the establishment of visible boundary markers and tablets; the construction of theme squares (Fig. 1) and monuments; the demarcation of buffer zones to prevent encroachment of constructions; the placement of panels or posters with science outreach; and the posting of directional signs along nearby roads.

This procedure for GSSPs serves as a reference standard to protect and document other important stratigraphic sections. This process includes:

\section{Governmental Announcement, Monument and Maintenance}

In addition to the official approval by provincial governments, it is recommended that the announcements be posted near the section to popularize its significance and legal protection (Fig. 2). Permanent markers range from small stone tablets to directional signs along main roads so that the public (and researchers) can easily find the locations (Fig. 3). Organizations in charge of the access, protection work and

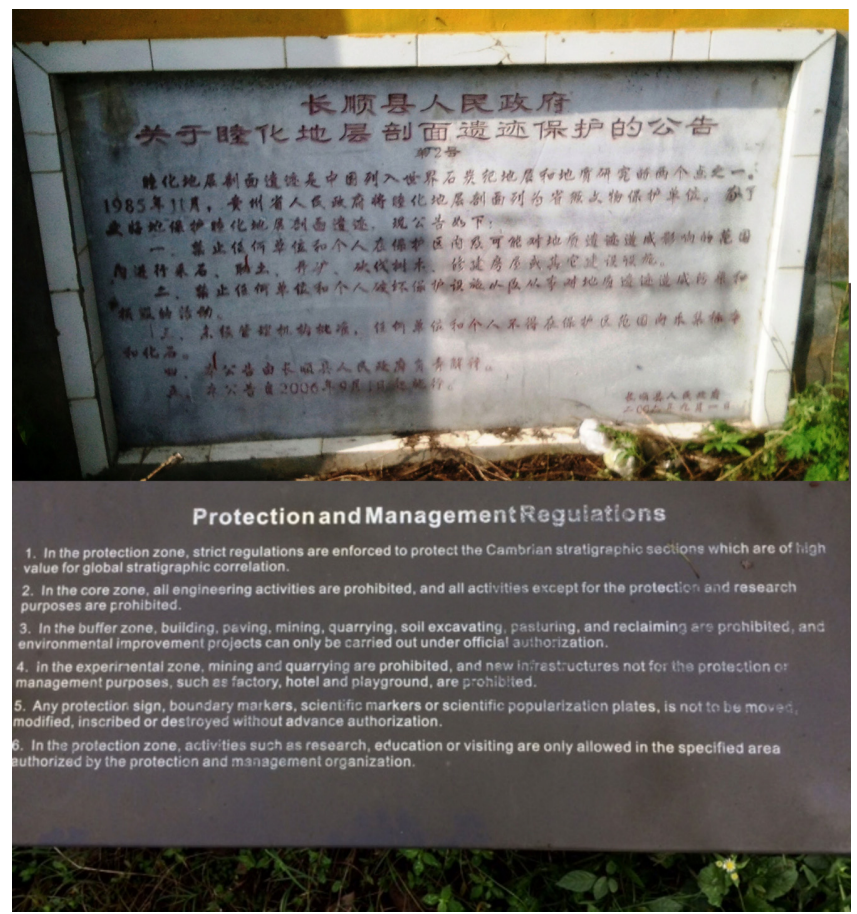

Figure 2. Stone tablets showing governmental announcement and management regulations for the section protection. Devonian-Carboniferous boundary section at Muhua of Changshun, Guizhou province above, and Jiangshanian Stage (within Upper Cambrian) GSSP at Jiangshan County of Zhejiang Province below (photo by H. Hou).
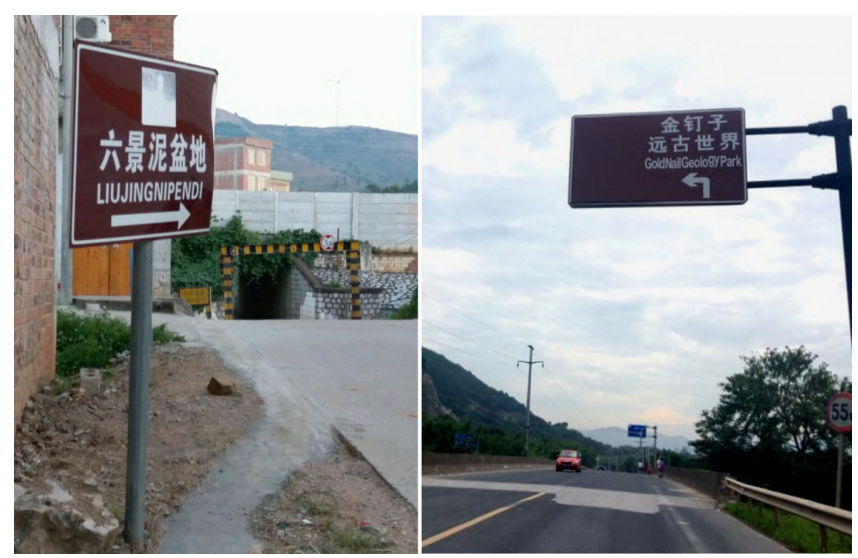

Figure 3. Road signs for the protected Devonian section by countryside road at Liujing, near Nanning City of Guangxi Zhuang Autonomous Region (left), and for the "Gold Nail" (= Golden Spike) Geopark at Meishan hosting the Changhxingian Stage and Permian-Triassic Boundary GSSPs by highway near Changxing County of Zhejiang Province (right). The Meishan quarry exposures are visible on the hillside (photo by W. Chen and L. Yu). 
maintenance are listed on the back or base of monuments. Clearance and re-excavation of stratigraphic sections, especially from the heavy vegetation in southern China or removing debris accumulations should be done to guarantee the full exposure of stratigraphic sections for the convenience of observation and research.

\section{Documentation}

Bed division and systematic measured thicknesses are the basis for a stratigraphic section. However, due to different concepts in stratigraphic division and to divergent purposes of research sampling, there can often arise inconsistencies or confusions by different research teams in assigning a particular stratigraphic "bed", numbering strata on outcrops. Sometimes adding to the bewilderment of new researchers, different numbers are marked for the same bed or independent researchers had assigned variable levels to the base of a "formation" or "member" in the same studied section. Diverse methods of measurement or of the recognition and compensation for minor fault offsets can result in different thicknesses for the same stratigraphic section.

Therefore, original materials about stratigraphic sections should be re-examined and re-evaluated to standardize the bed nomenclature and/or meter scale on the protected sections in order to have "common language". Based on our experience with different lithologic facies, we suggest the following methods for designating and marking a standard in-situ assignment of beds and scale for stratigraphic sections:

(a) Bed numbering. For well-cemented rocks, such as limestone and sandstone, bed numbers can be directly sculpted into the surface of each natural bed (Fig. 4). For sections with alternating hard and soft rocks, for instance limestone interlaced with shale and clay, bed numbers can be sculpted only on hard rocks (Fig. 5). Boundary tablets should be placed at the stratotype point or the section starting and finishing points and at each regional mapping unit (formation, mem-

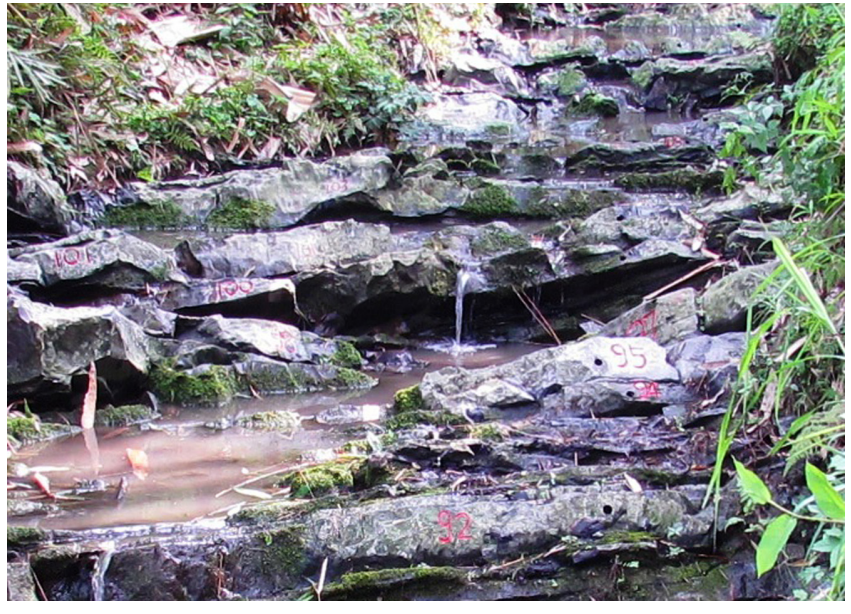

Figure 4. Bed numbers (red) engraved into the limestones of the Pengchong section (Visean GSSP, lower Carboniferous) near Liuzhou City of Guangxi Zhuang Autonomous Region (photo by H. Hou).

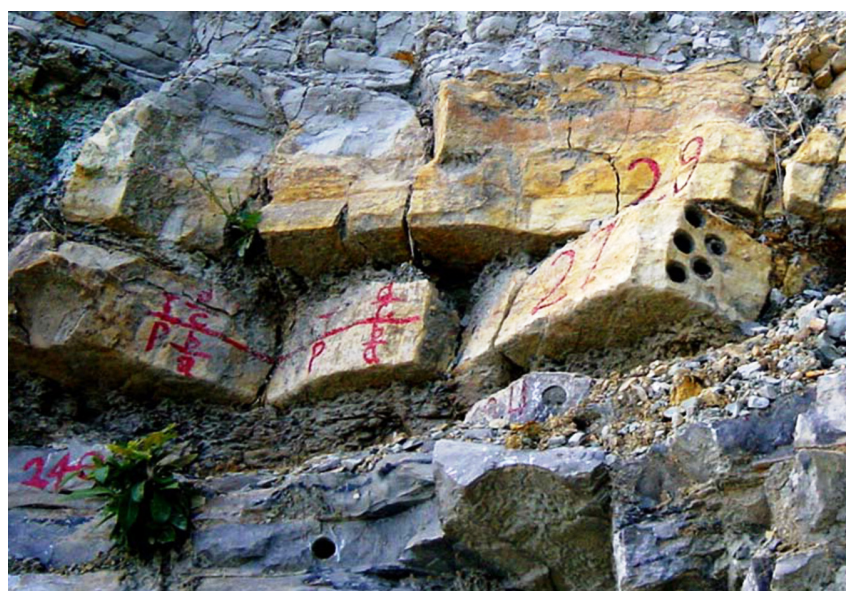

Figure 5. Bed numbers engraved into alternating hard and soft rocks of Permian-Triassic boundary section at Changxing Geopark, Meishan, Zhejiang province (photo by K. Zhang).
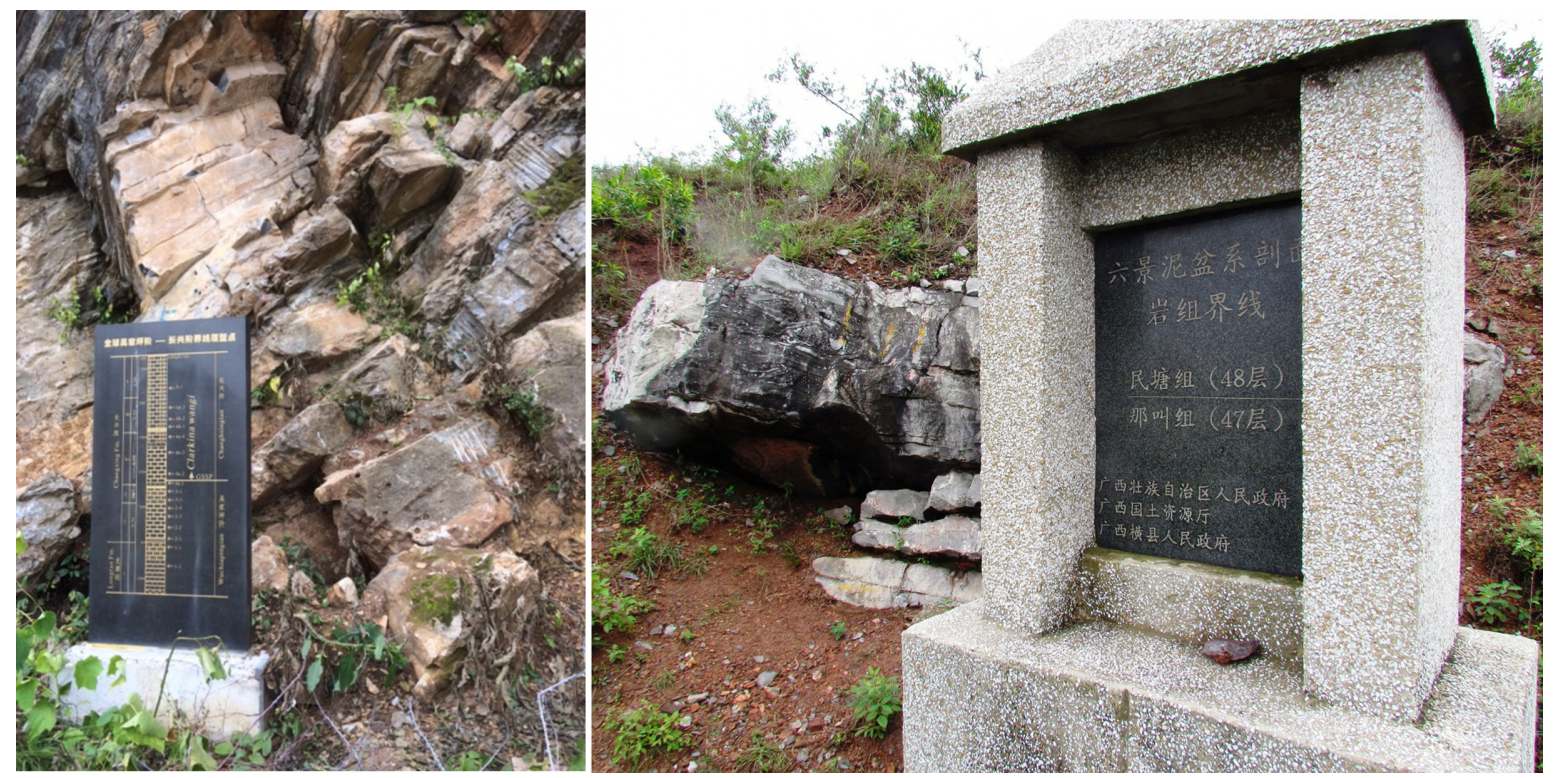

Figure 6. Stone tablets indicating the formation boundary between thin-bedded Mingtang Formation (bioclastic limestone) and underlying Najiao Formation (light gray dolomitic limestone) at Liujing, near Nanning of Guangxi Zhuang Autonomous Region (right), and the lithologic sequence around the Changhsingian Stage boundary GSSP at Meishan, Changxing County of Zhejiang Province (left) (photo by H. Hou). 
ber) (Fig. 6).

(b) Thickness scale. For a continuous stratigraphic section, its starting point is set as the zero point at an easily designated level, and aluminum rods sculpted with meter levels are embedded into holes drilled at appropriate intervals (e.g., $1 \mathrm{~m}$ or $5 \mathrm{~m}$ ). With this "common language", researchers only need to measure distances from their sampled layer to the neighboring aluminum sticks (Fig. 7) and assign the sample as " $\mathrm{xx} \mathrm{m}$ " above the zero point.

(c) Soft-sediment sections. For stratigraphic sections with fragile lithology or susceptible to heavy weathering, such as mudstone, clay, siliceous shale, thin-bedded limestone, it is very difficult to systematically and continuously mark numbers. In these cases, vertical grooves can be excavated into the section, filled in with concrete, and then marked with numbers (bed numbers, thickness or distance) to serve as the standardized scale (Fig. 8).

However, it must be recognized that all of these markers have a limited permanence. Therefore, it is essential that a detailed formal documentation, including extensive imagery of the section with anno-

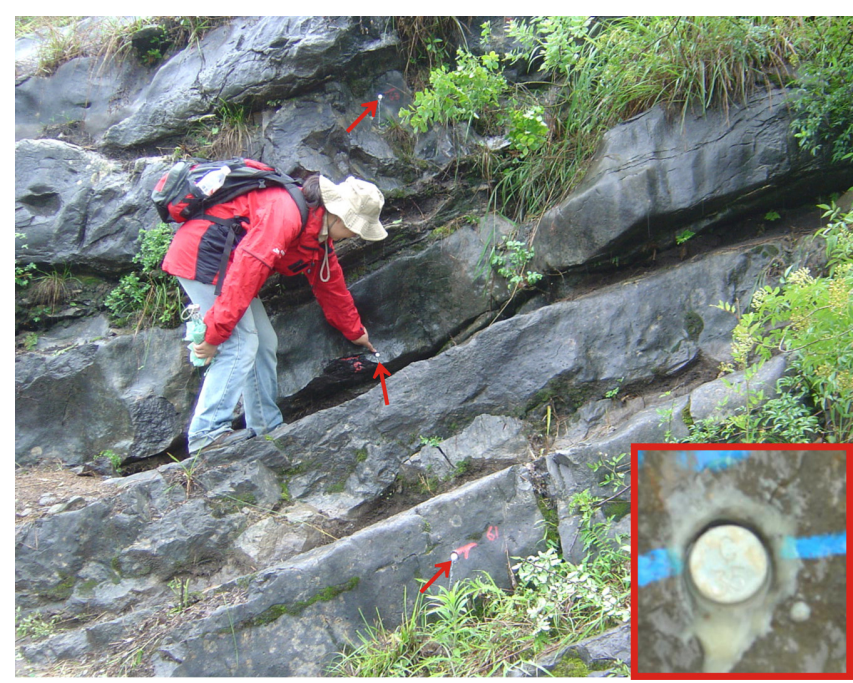

Figure 7. Aluminum plugs (red arrows) at standardized 1-m intervals embedded into a Serpukhovian (Carboniferous) limestone section at Yashui, Huishui County of Guizhou province (photo by X. Wang).

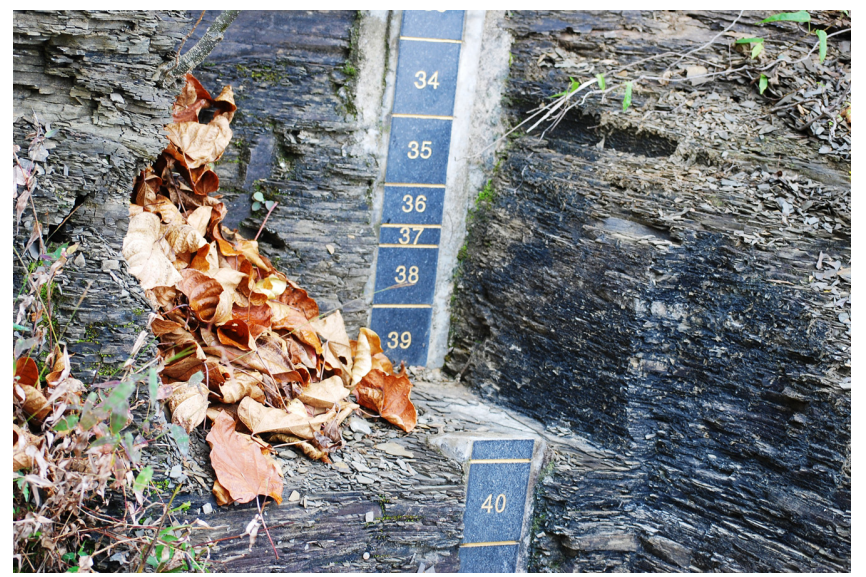

Figure 8. Reference scale of bed numbers cemented into the relatively poorly cemented rocks of Lower-Middle Cambrian formations at Jianhe County, Guizhou province (photo by X. Wu).

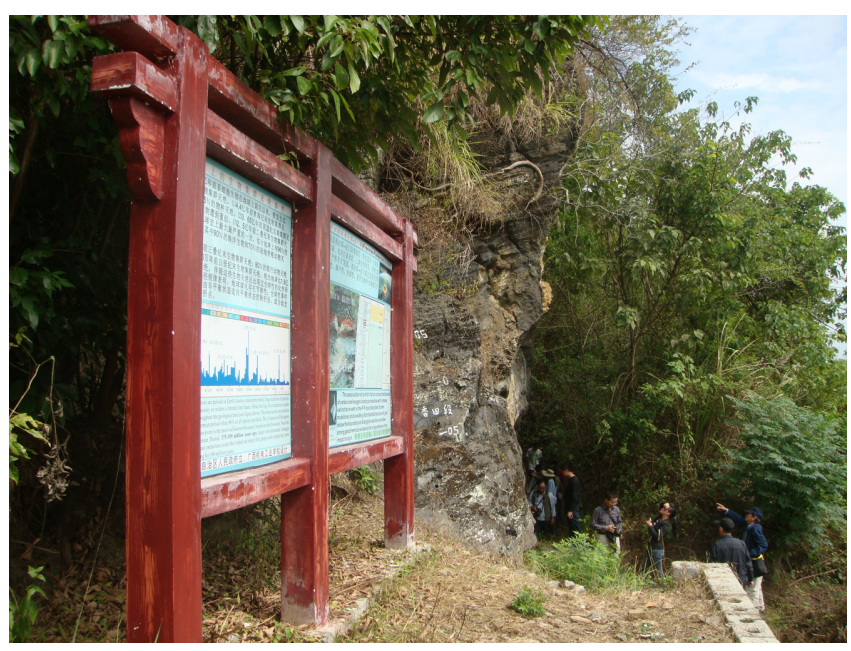

Figure 9. Educational posters near a protected section of Frasnian-Famennian (Late Devonian) event beds at Luoxiu, Xiangzhou County of Guangxi Zhuang Autonomous Region (Photo by H. Hou).

tated standardized numbering, be published and also be provided at the websites of the national stratigraphic commission and local government organizations. Future options will also include outcrop scanning, such as was used in the Digital Integrated Stratigraphy Project demonstration project on Silurian reference sections in Wales and western England (e.g., Munnecke et al., 2012).

\section{Integration of Section Protection and Science Popularization}

Only when the public is aware that important stratigraphic sections are a significant part of natural heritage can their protection gain extensive public support. Therefore, protection and documentation of important reference sections should be integrated with science popularization and promoted as resources for the youth to explore concepts of geoscience and learn Earth's history. It is advocated that geoscience panels in local and international languages be established in the conservation area near the stratigraphic section (Fig. 9).

\section{Field Guide}

In order to better serve the society, popularize geoscience and promote "DIY tours", field guides should be compiled in both local and international languages for audiences of specialists and the interested public. For typical stratigraphic sections, field guides use easily understood writing, maps and illustrations to clearly introduce related geoscience knowledge and should integrate multidisciplinary knowledge based on existing research results. Due to different nature of stratigraphic sections, there are no unified requirements but the main content shall include the following:

1) Foreword: geoscience background and significance of the stratigraphic section, research and protection processes, main research organizations and personnel, and contact details; 
2) Geographic location: longitude and latitude, geographic situation (topography, climate), transportation (how to get there), traffic and location maps;

3) Regional geology: tectonic and paleogeographic setting of the stratigraphic section, regional stratigraphic setting, geologic map, related stratigraphic tables with the marked location of the stratigraphic section;

4) Detailed introduction of the stratigraphic section: sedimentary characteristics as well as fossil distribution, events and sequences; columnar section, fossil distributions, isotopic dating and analysis results, photos and sketches, and references to publications related to the stratigraphic section.

\section{Summary}

For the registered stratigraphic sections in China, only about one third have not yet been protected or marked in any format. The ongoing protection and documentation projects for outreach should follow the requirements of "four ones" - one monument, one set of signs, one series of science popularization panels and one field guide - to gradually push forward standardization of protection work in an orderly manner. There is still a long way to go to realize the full suite of identification, documentation, and protection of stratigraphic sections. This protection process in China is for the benefit of present and future generations of researchers and interested public; and we recommend that other nations strive to identify and protect their significant global stratigraphic reference sections.

\section{Acknowledgements}

We thank Stan Finney (Episodes handling editor), Asier Hilario Orús and an anonymous reviewer for constructive comments and recommendations that improved the text and figures.

\section{References}

An, Z., Lui, T., Porter, S.C., Kukla, G., Wu, X., and Hua, Y., 1990, The long-term paleomonsoon variation record by the loess-paleosol sequence in central China. Quaternary International, v. 7/8, pp. 91-95.

Chang, M.M. (chief-in-editor), 2004, The Jehol Biota - The Emergence of Feathered Dinosaurs, Beaked Birds and Flowering Plants. Shanghai Scientific and Technical Publishers, Shanghai, $205 \mathrm{p}$.

Chen, J.B., Zhang H.M., Zhu S.X., Zhao Z., and Wang Z.G., 1980, Research on Jixian Suberathem of Jixian County, Tianjin. Tianjin Science and Technology Press, Tianjin.

Ding, Z.L., Derbyshire, E., Yang, S.L., Yu, Z.W., Xiong, S.F., and Liu, T.S., 2002, Stacked 2.6-Ma grain size record from the Chinese loess based on five sections and correlation with the deep-sea $\delta^{18} \mathrm{O}$ record. Paleoceanography, v. 17, pp. 1033. doi: 10.1029/2001PA000725

Fan, J.X., Peng, S.C., Hou, X.D., and Chen, D.Y., 2015, Website of the International Commission on Stratigraphy and International Geologic Time Scale (2015/01 Edition). Journal of Stratigraphy, v. 39, pp. 125-
134.

Gradstein, F.M., Ogg, J.G., Schmitz M.D., and Ogg, G.M., 2012, The Geological Time Scale 2012 (2 volumes). Elsevier, Amsterdam, 1174 p.

Lee, Y.Y., 1936, The Sinian glaciation in the lower Yangtze valley. Bulletin of the Geological Society of China, v. 5, pp. 131-134.

Ministry of Geology and Mineral Resources of China, 1995, Regulations on Geoheritage Protection (promulgated on May $4^{\text {th }}, 1995$ ).

Munnecke, M., Cramer, B.D., Boon, D.P., Kharwat, R., Aiken, C.L., and Schofield, D.I., 2012, The Digital Integrated Stratigraphy Project (DISP). Bulletin of Geosciences, v. 87, pp. 705-712.

Peng, S.C., Hou, H.F., and Wang, X.F., 2016, The Global Stratotypes in China. Shanghai Science and Technology Publishers, Shanghai, 359 p.

Zhang, S.G., Zhang, Y.B., and Yan, H.J., 2015, International Geologic Time Scale (2014). Journal of Stratigraphy, v. 39, pp. 359-366.

Zhang, S.H., Jiang, G.Q., and Han, Y.G., 2008, The age of the Nantuo Formation and Nantuo glaciation in South China. Terra Nova, v. 20, pp. 289 294.

Zheng, Y.F., Wu, Y.B., Gong, B., Chen, R.X., Tang, J., and Zhao, Z.F., 2007, Tectonic driving of Neoproterozoic glacistions: evidence from extreme oxygen isotope signature of meteoric water in granite. Earth and Planetary Science Latters, v. 256, pp. 196-210.

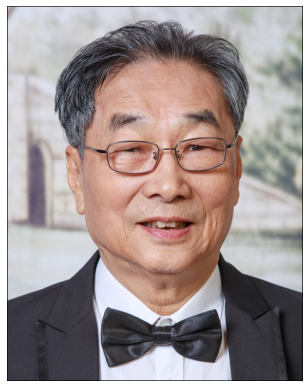

Zejiu Wang was Vice President of the Chinese Academy of Geological Sciences. His career has centered on management of geosciences, international exchange and research on Precambrian geology of China. Since 2000, as General Secretariat and Executive Vice Chairman of China National Commission on Stratigraphy, he is in charge of projects on China stratigraphic lexicon and China Stratigraphical Chart.

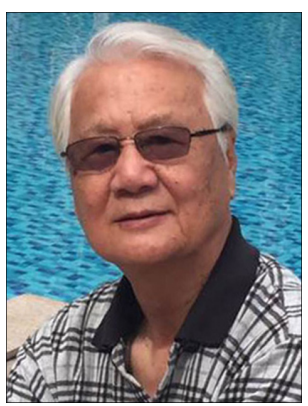

Hongfei Hou is a Research Fellow at Institute of Geology, CAGS, China. Following his retirement in 1996 he served, as Managing Editor, Episodes Journal of IUGS (1997-2008). His interests are bio- and event stratigraphy, brachiopoda paleontology and paleogeography of Devonian and Lower Carboniferous. He is currently involved with protection of stratigraphic sections as Vice Chairman of Subcommission on Stratigraphic Section Protection, CNCS.

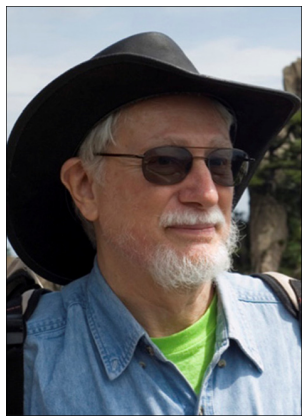

James Ogg is a Professor of geology at Purdue University in USA, and Visiting Professor at Chinese University of Geosciences (Wuhan). He specializes in integrated geologic time scales and databases. He was the former Secretary General (2000-2008) of the International Commission on Stratigraphy, and is now cooperating with China National Commission on Stratigraphy on calibration and on-line access to their regional geologic history. 